\title{
DUPLEX PCR FOR DETECTION OF ALEUTIAN DISEASE VIRUS FROM BIOLOGICAL AND ENVIRONMENTAL SAMPLES
}

\author{
KOWALCZYK Marek, JAKUBCZAK Andrzej, GRYZIŃSKA Magdalena* \\ Institute of Biological Basis of Animal Production, Faculty of Animal Sciences and Bioeconomy, \\ University of Life Sciences in Lublin, Poland
}

(Received 26 June, Accepted 13 November 2019)

\begin{abstract}
Aleutian disease is one of the most serious disease entities affecting mink farms. The disease causes significant economic losses in mink breeding countries. The aim of the study was to optimize a diagnostic test based on duplex PCR to enable detection of Aleutian disease virus in biological and environmental samples.

Blood $(n=40)$ and spleen $(n=40)$ samples from animals with suspected infection, and swabs from cages in which infected animals were kept $(n=20)$ were used for analysis. DNA was isolated from the samples, followed by optimization of the duplex PCR reaction targeting sequences coding NS1 and VP2 proteins. The qPCR method was used to determine the sensitivity of the reaction. The specificity of the analysis was confirmed by the sequencing results.
\end{abstract}

Optimized duplex PCR enabled detection of Aleutian Mink Disease Virus (AMDV) genetic material in biological and environmental samples. Testing of the sensitivity of the method indicated clear amplification for both primer pairs at $10^{2}$ copies of viral DNA in a reaction. Sequencing confirmed the specificity of the reaction, which in the case of both primer pairs indicated an over $90 \%$ agreement between the isolates and the variants of the virus from the databases.

The use of duplex PCR to detect two regions of the AMDV genome may increase the sensitivity and specificity of the method and significantly expand the possibilities of further analysis based on sequencing.

Keywords: Aleutian disease, diagnostics, duplex PCR, optimization

\section{INTRODUCTION}

Aleutian Mink Disease Virus (AMDV) has been known since the mid-1950s and remains one of the main causes of health problems on mink farms. The disease takes a varied course, from asymptomatic infections to subclinical infections to progressive infections [1,2]. AMDV stimulates the host lymphocytes to overproduce plasma cells and antibodies, which is why Aleutian disease is also called plasmacytosis. In

*Corresponding author: e-mail: magdalena.gryzinska@up.lublin.pl 
consequence, antibodies and virions form complexes which are deposited in tissues, leading to inflammation of the target organs, such as the kidneys, liver and lungs. In addition to high pre-weaning mortality rates, the pathogen reduces fecundity in females and thus breeding efficiency [3]. Despite attempts to develop specific immunoprophylactic methods and drugs [4,5], there is still no effective treatment for Aleutian disease.

The high level of molecular polymorphism of the pathogens is one of the main reasons for the failure of diagnostic techniques and immunoprophylactic measures. The mutating virus can change its antigenic structure, making serological diagnostics difficult [6]. Mutations can alter the antigenicity of a protein, which may lead to vaccine failure and to the loss of the ability to detect the virus in serologic tests [7].

There are methods based on the amplification and further detection of viral DNA enabling more sensitive diagnostics [6]. However, molecular methods are also subject to a lack of specificity resulting from the high variability of the pathogen. Potential presence of mutations within the primer or probe-binding sites prevent annealing, amplification and subsequent detection of viral genetic material [8,9]. Therefore, despite its high sensitivity and specificity, the PCR method may give false negative results, due to a low viral titer in the test sample or to polymorphisms at the primer annealing sites.

AMD virus, similarly to other parvoviruses [10], displays high mutation rate, which may hindered diagnostics by PCR and lead to failure in diagnostics. Therefore it is necessary to search for the alternative solutions, which can enhance the sensitivity of the diagnostics methods. The number of false negative results can be reduced by simultaneous amplification of several sites of the target genome. The effect is achieved by designing a multiplex reaction, using multiple primer pairs.

Taking into account the high molecular polymorphism of AMD virus and the role of diagnostics in eradication of AMDV development of new diagnostics methods seems to be crucial. The aim of the study was to optimize a duplex PCR reaction enabling the simultaneous amplification of fragments of both the NS1 non-structural protein and the VP2 structural protein, and to assess the effectiveness of the method in detecting AMDV from biological and environmental samples.

\section{MATERIAL AND METHODS}

\section{Sample collection}

The farm and animals for testing were selected based on positive results of countercurrent immunoelectrophoresis (CIEP). To evaluate the effectiveness of the method in detecting AMDV from various types of biological material, we analyzed blood ( $\mathrm{n}$ $=40)$ and spleens $(\mathrm{n}=40)$ taken post-mortem from animals with suspected Aleutian disease, as well as swabs from the cages the infected animals were kept in $(n=20)$. In each of the samples, the result was confirmed by qPCR. 
To design a diagnostic algorithm for simultaneous detection of the virus in a large group of animals, we tested the possibility of using pooled samples. In the case of blood samples, pooled samples were analyzed in addition to individual diagnosis. A $40 \mu \mathrm{l}$ volume of blood from 10 animals was mixed and the pooled samples obtained were treated as single samples during isolation and further analysis. The research was carried out in accordance with the standards recommended by the Second Local Ethics Committee on Animal Experiments at the University of Life Sciences in Lublin, resolution no. 30/2010.

\section{Isolation of genetic material}

The DNeasy Blood and Tissue Kit (Qiagen, Hilden, Germany) was used to isolate DNA from the blood and spleens. The tissue was homogenized with ATL lysis buffer in a TissueLyser II apparatus (Qiagen) at a frequency of $20 \mathrm{hz}$ for $20 \mathrm{~s}$ and incubated until complete lysis was obtained. Elution was performed in a 150 ul volume. Isolation from the blood was carried out according to the protocol provided with the kit. DNA was eluted in a volume of $100 \mathrm{ul}$.

Swabs were incubated with shaking for $2 \mathrm{~h}$ in PBS at $37^{\circ} \mathrm{C}$, followed by isolation with the DNeasy Blood \& Tissue Kit (Qiagen). Lysis was performed in $400 \mathrm{ul}$ of AL buffer and $20 \mathrm{ul}$ of proteinase $\mathrm{K}$ for $1 \mathrm{~h}$. Further isolation steps were carried out according to the manufacturer's protocol. For elution, 100 ul of AE buffer was used.

\section{PCR amplification}

For the PCR reaction we used a pair of primers amplifying a fragment of the NS1 protein - forward primer 5' CATATTCACTGTTGCTTAGGTTA 3' and reverse primer 5' CGTTCTTTGTTAGTTAGGTTGTC 3' [11] (product length 374bp) and a pair amplifying a fragment of the VP2 structural protein - the forward primer 5' TCTAGAAGCAACGCT'TGGGGTGTATG 3' and the reverse primer 5' GTTGTGTCACTCCACTGTCT 3' (product length 802bp) [12].

To obtain the most effective conditions for the analysis, a preliminary optimization of the reaction was carried out in a temperature gradient of $48-58^{\circ} \mathrm{C}$, followed by optimization proper in a narrower range $\left(56-61^{\circ} \mathrm{C}\right)$ and in a gradient of magnesium concentrations $(2.5 \mathrm{mM}, 3 \mathrm{mM}$ and $3.5 \mathrm{mM})$. After the preliminary analysis, the chemical and thermal profile of the reaction was established. The reaction mixture contained $3 \mu \mathrm{l}$ DNA and 1 U Taq polymerase AmpliTaq Gold 360 DNA Polymerase (Applied Biosystems, Foster City, CA) in the manufacturer's buffer, adjusted to a final concentration of $3.0 \mathrm{mM} \mathrm{MgCl}, 0.8 \mathrm{mM}$ of each dNTP and $1.2 \mathrm{mM}$ of each primer $-25 \mu \mathrm{L}$ total volume. PCR cycling conditions were $95^{\circ} \mathrm{C}$ for $10 \mathrm{~min}, 40$ cycles of $95^{\circ} \mathrm{C}$ for $45 \mathrm{~s}, 59^{\circ} \mathrm{C}$ for $45 \mathrm{~s}, 72^{\circ} \mathrm{C}$ for $60 \mathrm{~s}$, and $72^{\circ} \mathrm{C}$ for $10 \mathrm{~min}$ in Labcycler (SensoQuest,Göttingen, Germany).

To confirm the PCR products, gel electrophoresis was carried out using a $2 \%$ agarose gel with ethidium bromide (EtBr). 


\section{Evaluation of the sensitivity of the duplex PCR reaction}

Quantitative determination of the number of copies of genetic material of the virus was carried out by the qPCR method using a commercial assay for Aleutian Disease Virus (Gensig AIDV advanced Kit - PrimerDesign ${ }^{\text {TM }}$ Ltd., Eastleigh UK) in an ABI Prism ${ }^{\circledR} 7500$ Fast apparatus (Applied Biosystems). Serial dilutions of $2 \times 10^{5}$ copies / $\mu 1,2 \times 10^{4}$ copies $/ \mu 1,2 \times 10^{3}$ copies $/ \mu 1,2 \times 10^{2}$ copies $/ \mu 1,2 \times 10^{1}$ copies $/ \mu l$ and $2 \times$ $10^{0}$ copies $/ \mu$ l were used to prepare the standard curve. These dilutions were prepared using the positive control supplied with the kit. Quantitative determination was performed in order to determine the average number of copies of viral DNA in each of the materials tested and to assess the sensitivity of the method. To determine the sensitivity of the method, decimal dilutions of the samples quantitatively determined by qPCR were prepared (containing $10^{8}, 5 \times 10^{7}, 10^{7}, 10^{6}, 10^{5}, 10^{4}, 10^{3}, 10^{2}, 5 \times 10^{1}$, and $10^{1}$ copies of the virus per reaction) and duplex PCR was carried out for them.

\section{Evaluation of the specificity of the reaction}

To confirm the specificity of the reaction, selected PCR products from the blood (n $=10)$ and spleens $(n=10)$ were sequenced, for both the NS1 and the VP2 protein sequence. The PCR products were purified using the Exo SAP-IT kit (Affymetrix, CA, USA). Sequential PCR was performed for forward and reverse primers using the BigDye Terminator v 3.1 Cycle Sequencing Kit (Applied Biosystems). The sequencing PCR products were purified with the ExTerminator kit (A\&A Biotechnology, Gdynia, Poland), subjected to thermal denaturation in the presence of formamide, and separated on an ABI PRISM 3100-Avant Genetic Analyzer (Applied Biosystems).

Contig assembly and analysis of sequencing results were carried out in Baser DNA software. The specificity was determined using the BLAST application and by comparing the sequences obtained with the GenBank bioinformatic database. Phylogenetic analysis was carried out in MEGA6. A phylogenetic tree was obtained by the Maximum Likelihood method with 1000 bootstrap replications for the sequence coding NS1 protein as this fragment has been used to analysis of relationships between isolates and tracing of outbreaks [13,14].

\section{RESULTS}

Based on the nucleotide composition of the primers used for the reaction, preliminary optimization was performed in a temperature gradient of $50-60^{\circ} \mathrm{C}$. Since better amplification efficiency was observed at higher temperatures, additional optimization was performed in a narrower temperature range of $56-61^{\circ} \mathrm{C}$, and the best amplification efficiency was obtained at $59^{\circ} \mathrm{C}$. The reaction was also optimized in a magnesium gradient. The best results were obtained at a concentration of magnesium ions at the level of $3 \mathrm{mM}$. Given that two primer pairs are amplified in a single reaction, $1 \mathrm{~min}$ was considered the optimal elongation time. 
To determine the sensitivity of the method, qPCR was performed to determine the viral load in samples isolated from the spleen, and then decimal dilutions of the starting material were prepared (Figure 1). The average number of virus copies in the spleen was $10^{8}$ per reaction. The amount of viral genetic material detected in the blood tested individually was $10^{4}$ copies per reaction, in pooled blood $10^{3}$, and in environmental samples $10^{2}$ copies per reaction.
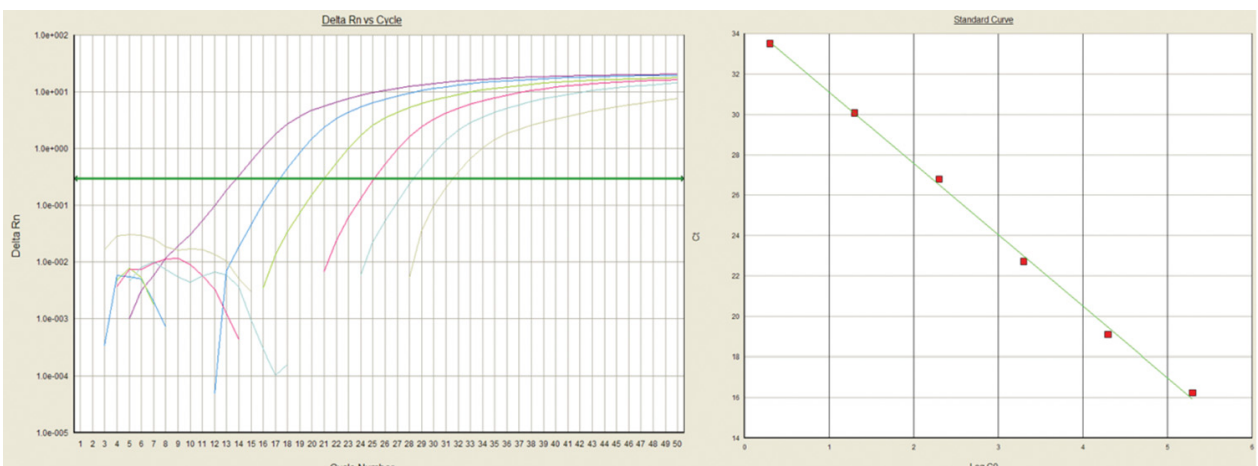

Figure 1. Standard curve obtained during qPCR analysis, used to determine the number of copies in the samples

Amplification of the diluted genetic material yielded a result for two primer pairs in the samples with $10^{2}$ copies of the genetic material of the virus (Figure 2). For samples with $5 \times 10^{1}$ or $10^{1}$ copies, a weak positive result was obtained for the primer amplifying the non-structural protein coding sequence, while in the case of the primers flanking the VP2 protein coding sequence, no amplification occurred for the last two dilutions (wells 9 and 10).

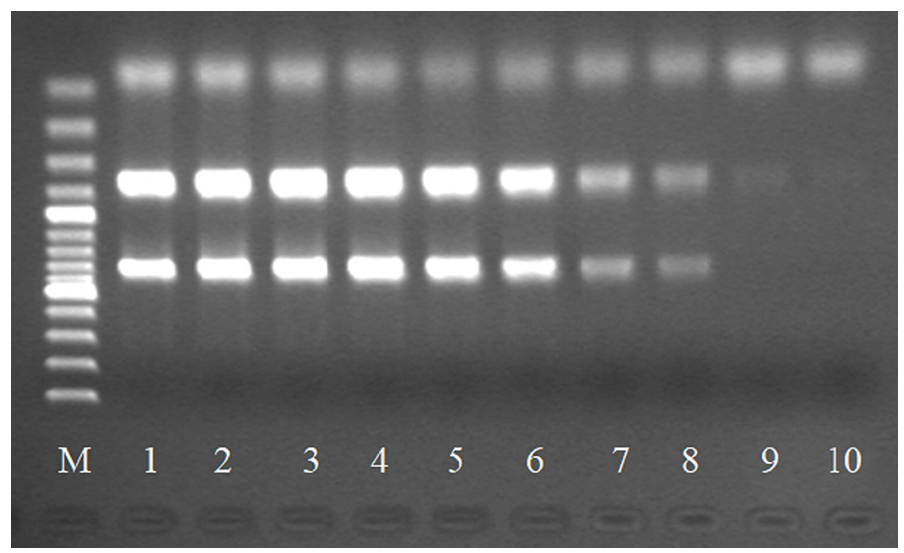

Figure 2. Assessment of duplex PCR sensitivity: $\mathrm{M}$ - size marker $-100 \mathrm{bp}, 1-1 \times 10^{8}$, $2-5 \times 10^{7}, 3-1 \times 10^{7}, 4-1 \times 10^{6}, 5-1 \times 10^{5}, 6-1 \times 10^{4}, 7-1 \times 10^{3}, 8-1 \times 10^{2}, 9-5 \times 10^{1}, 10-1 \times 10^{1}$ 
Sequencing results and bioinformatic analysis confirmed the specificity of the reactions for both primer pairs. Based on the coding sequence of the NS1 protein, two variants were distinguished, with over $99 \%$ similarity to one another. The similarity to variants from the GenBank database ranged from $82 \%$ (strain M195) to over $95 \%$ (Utah strain). All sequenced isolates had identical VP2 protein sequences and showed more than 94\% similarity to the ADV-LN3 strain and more than $90 \%$ similarity to other AMDV sequences deposited in the NCBI database (Table 1).

Table 1. Similarity in nucleotide sequences coding for NS1 and VP2 proteins between the test isolates and sequences deposited in the GenBank database

\begin{tabular}{|c|c|c|c|c|}
\hline \multirow{2}{*}{ Sequences } & \multicolumn{2}{|c|}{ NS } & \multicolumn{2}{|c|}{ VP2 } \\
\hline & A1 & A2 & A1 & A2 \\
\hline A1 & ID & $99.60 \%$ & ID & $100.00 \%$ \\
\hline A2 & $99.60 \%$ & ID & $100.00 \%$ & ID \\
\hline KU513988.1_Utah & $95.70 \%$ & $95.30 \%$ & $91.60 \%$ & $91.60 \%$ \\
\hline JN040434.1_AMDV-G & $84.10 \%$ & $84.40 \%$ & $91.50 \%$ & $91.50 \%$ \\
\hline GU183264.1_ADV-LN1 & $91.70 \%$ & $92.00 \%$ & $93.10 \%$ & $93.10 \%$ \\
\hline GU183265.1_ADV-LN2 & $94.00 \%$ & $93.70 \%$ & $93.10 \%$ & $93.10 \%$ \\
\hline GU269892.1_ADV-LN3 & $92.00 \%$ & $92.40 \%$ & $94.40 \%$ & $94.40 \%$ \\
\hline KT878958.1_M173 & $92.00 \%$ & $91.70 \%$ & $92.50 \%$ & $92.50 \%$ \\
\hline KY680280.1_strain_LM & $87.40 \%$ & $87.10 \%$ & $92.50 \%$ & $92.50 \%$ \\
\hline KT878959.1_strain_M195 & $82.80 \%$ & $82.50 \%$ & $92.70 \%$ & $92.70 \%$ \\
\hline KT878960.1_strain_M228 & $91.70 \%$ & $91.40 \%$ & $91.80 \%$ & $91.80 \%$ \\
\hline KT878961.1_strain_WM25 & $94.30 \%$ & $94.00 \%$ & $92.90 \%$ & $92.90 \%$ \\
\hline KT329428.1_Beijing & $85.80 \%$ & $85.40 \%$ & $93.50 \%$ & $93.50 \%$ \\
\hline KU513985.1_isolate_G*1 & $84.10 \%$ & $84.40 \%$ & $91.50 \%$ & $91.50 \%$ \\
\hline KU513986.1_isolate_G*2 & $84.10 \%$ & $84.40 \%$ & $91.50 \%$ & $91.50 \%$ \\
\hline KU513987.1_isolate_G*3 & $84.10 \%$ & $84.40 \%$ & $91.50 \%$ & $91.50 \%$ \\
\hline
\end{tabular}

Phylogenetic analysis indicated that obtained variants share the same clade with the Utah and ADV-LN1-3 strains, whereas non-pathogenic strain - AMDV-G formed separate, distant clade (Figure 3).

After analyzing the sensitivity and specificity of the method, we evaluated its effectiveness in detecting AMDV in the spleen, blood and pooled blood. A clear amplification product with both primers was obtained for all the spleen tissue, in which the average number of copies detected by qPCR was $10^{8}$ per reaction. In the case of individually tested blood samples as well, clear bands were obtained for the primers flanking both the NS1 and the VP2 fragments (Figure 4). The results of the duplex PCR reaction confirmed the possibility of testing pooled blood samples, as clear amplification products were obtained for both primers despite the lower viral 
load (the average viral load in pooled blood as determined by qPCR was $10^{4}$ copies per reaction).

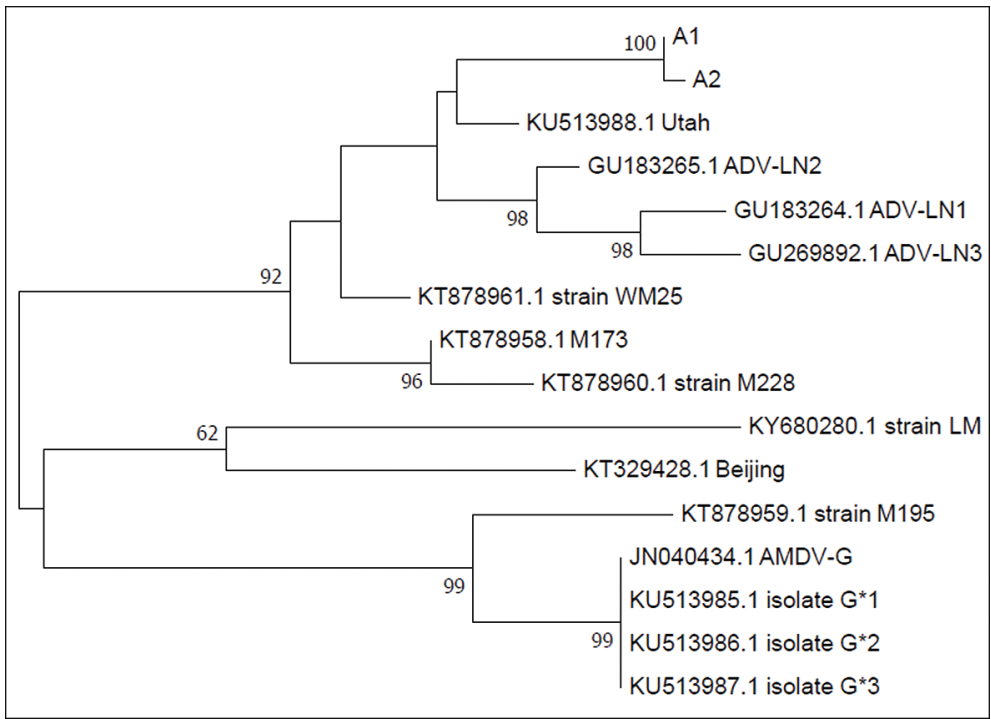

Figure 3. Result of phylogenetic analysis between obtained variants and sequences from GenBank database. Phylogenetic tree was based on the sequence coding NS1 protein and prepared by MEGA 6 using the maximum likelihood method with 1,000 bootstrap replicates

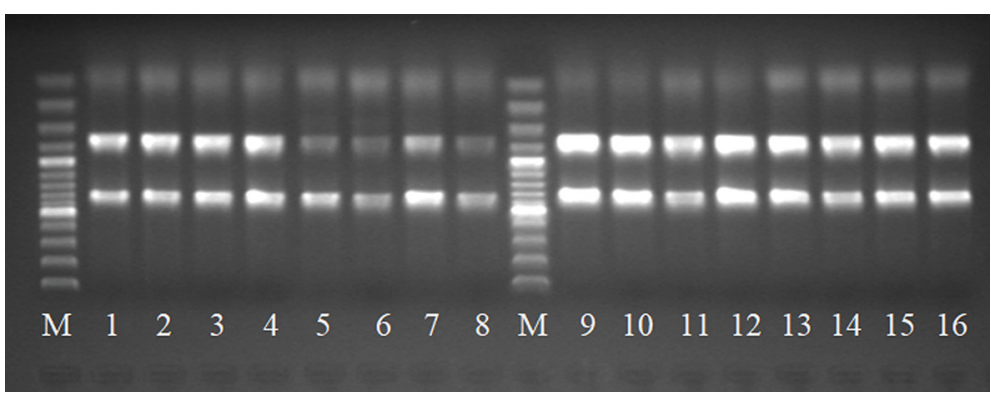

Figure 4. Electrophoretic separation of PCR products: M - 100 bp marker, reaction results for samples isolated from blood tested as individual samples (wells 1-4), pooled blood (5-8) and spleens (9-16)

In the case of PCR for DNA isolated from environmental samples, a positive result was obtained for the primers amplifying the non-structural protein for each of the samples tested. In the case of the fragment encoding the VP2 protein, in two cases a weak positive result was obtained, and in the others a false negative result (Figure 5). The average number of copies of the genetic material of the virus determined by the qPCR method was $10^{2}$. The lack of amplification for the primers flanking the VP2 protein sequence may be due both to the presence of polymerase inhibitors that reduce amplification efficiency and to the higher degree of DNA degradation in the environmental samples. 


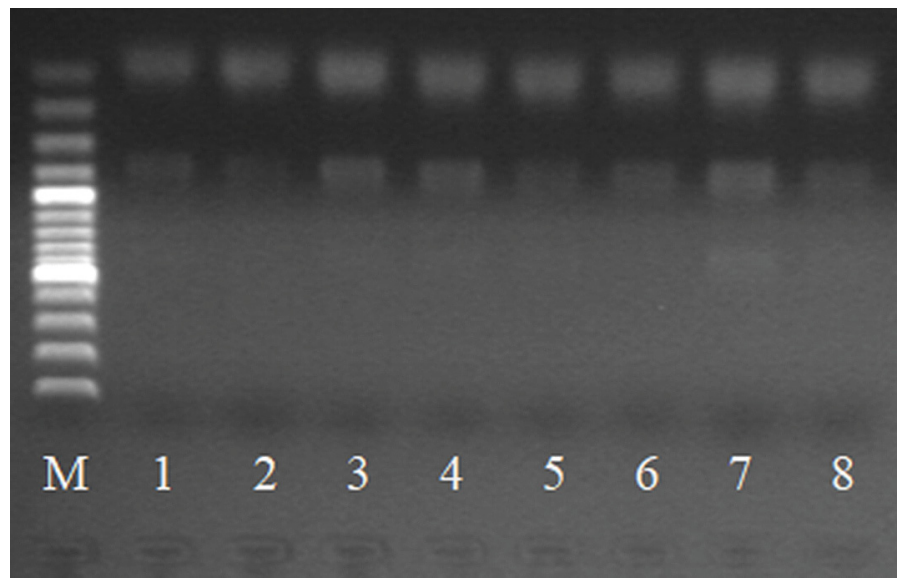

Figure 5. Electrophoretic separation of PCR products: $\mathrm{M}-100$ bp size marker, reaction results for samples isolated from swabs from the breeding environment $-1-8$

\section{DISCUSSION}

Many authors report a high mutation rate in the genome of parvoviruses. High genetic variability is also observed in the case of the Aleutian virus, which belongs to the family Parvoviridae. There are reports of numerous variants occurring on a single farm [15], or even co-infections of one host with several variants [16]. Not only can high genetic variability cause changes in antigenic properties and the appearance of falsenegative results in serological methods [17], but due to the occurrence of mutations at primer binding sites, it can result in decreased efficacy or even a lack of amplification in diagnostics based on classic PCR.

The multiplex PCR method is increasingly used in animal diagnostics; examples include testing of material for several pathogens simultaneously $[18,19]$. The approach used in the present study, consisting in the amplification of two regions in the genome of the same pathogen, has been used in many studies confirming the greater specificity of multiplex reactions [20-22]. The multiplex RT-PCR technique, simultaneously amplifying fragments of the H5, N1 and $\mathrm{M}$ genes, has been used to diagnose avian influenza, with the sensitivity of the assay specified at $10^{3}$ copies/ul [23].

The method of testing pooled samples presented in our study is a solution that allows for quick and sensitive diagnosis of a large group of animals in a short time and at lower cost than in the case of individual diagnosis. The average viral load in the blood of the animals was $10^{4}$ copies per reaction, which confirms the possibility of testing pooled samples from many animals while maintaining the high reliability of the test. Pooled samples have been tested by molecular methods, for example, to diagnose mastitis [24] and BVDV infections in cattle [25] , infections with classical swine fever virus in a wild boar population [26], and Coxiella burnetii infection, which causes abortion in sheep [27]. 
When selecting primers for the reaction, not only the diagnostic aspect was considered, but also the potential use of the method for genotyping and analysis of variation between isolates. Given the resources of bioinformatic databases of AMDV sequences, it seems reasonable to select primers that flank the most frequently deposited sequences, in order to allow global analysis of the epidemiology of the virus. The primers used in our research have previously been used in single reactions in a study on phylogenetic analyses between AMDV isolates [28,15]. Phylogentic analysis based on the sequence coding NS1 protein confirmed that obtained variants belong to the clade with the highly pathogenic strains Utah, and ADV-LN1-3 [29] and are distant from non-pathogenic AMDV-G, which forms separate clade. These relationships, may partially explain relatively high mortality rate of minks in tested farm.

There have been many reports on the possibility of using PCR in the diagnosis of viral diseases in mink [11, 30]. Moreover, qPCR method can be used to analyse the sanitary state of the environment in terms of AMDV epidemiology $[14,31,32]$. While the qPCR reaction is more sensitive, it is difficult to introduce for routine diagnostics due to its relatively high cost. The method presented in this paper proved highly suitable for detecting the virus in biological material, resulting in detection of the pathogen at the level of $10^{2}$ copies. This should be a sufficient sensitivity threshold in the case of blood samples, including pooled samples $\left(10^{3}\right.$ copies of the genetic material of the virus) and tissues of infected animals. The use of this method to test environmental samples is limited, and depends on the viral load in the test sample and the presence of potential inhibitors.

The proposed method can help with early detection of the virus and the introduction of effective measures to eliminate AMDV from infected farms. By using a protocol including pooling of samples, entire mink sheds can be quickly scanned for the presence of AMDV, and the high sensitivity of the proposed reaction and its ability to detect the pathogen from different types of material confirms its effectiveness and universality. In addition, the selection of primers not only enables detection of AMDV, but is the basis for further analysis and genotyping of the pathogen in terms of polymorphisms in both the NS1 and VP2 protein sequences, so that circulation of the virus between locations with outbreaks of the disease can be analyzed.

\section{Authors' contributions}

KM design of the study, PCR optimization, amplification and electrophoresis of obtained fragments, qPCR analysis, bioinformatics processing obtained results, preparing and formatting the manuscript to publication. JA is co-author of research hypothesis, preparing and formatting the manuscript to publication, qPCR analysis. GM preparing and formatting the manuscript to publication. All authors have approved the final version of the manuscript. 


\section{Declaration of conflicting interests}

The author(s) declared no potential conflicts of interest with respect to the research, authorship, and/or publication of this article.

\section{REFERENCES}

1. Farid AH, Ferns LE: Reduced severity of histopathological lesions in mink selected for tolerance to Aleutian mink disease virus infection. Res Vet Sci 2017, 111:127-134.

2. Kowalczyk M, Jakubczak A, Horecka B, Kostro K: A comparative molecular characterization of AMDV strains isolated from cases of clinical and subclinical infection. Virus Genes 2018, 54:561-569.

3. Ma FS, Zhang L, Wang Y, Lu RG, Hu B, Lv S, Xue XH, Li XT, Ling MY, Fan SN, Zhang HL, Yan XJ: Development of a Peptide ELISA for the Diagnosis of Aleutian Mink Disease. Plos One 2016, 11

4. Porter DD, Porter HG, Larsen AE: Pathogenesis of Aleutian disease of mink .2. enhancement of tissue lesions following administration of a killed virus-vaccine or passive antibody. J Immunol 1972, 109:1-7.

5. Aasted B, Alexandersen S, Christensen J: Vaccination with Aleutian mink disease parvovirus (AMDV) capsid proteins enhances disease, while vaccination with the major non-structural AMDV protein causes partial protection from disease. Vaccine 1998, 16:1158-1165.

6. Nguyen LT, Dunford L, Freitas I, Holder P, Nguyen LA, O’Gorman J, Connell J, Carr M, Hall W, De Gascun C: Hepatitis C Virus Core Mutations Associated with False-Negative Serological Results for Genotype 3a Core Antigen. J Clin Microbiol 2015, 53(8):2697-700.

7. Santana LC, Mantovani NP, Ferreira MC, Arnold R, Duro RLS, Ferreira PRA, Hunter JR, Leal É, Diaz RS, Komninakis SV: Identification of a new hepatitis B virus recombinant D2/D3 in the city of Sao Paulo, Brazil. Arch Virol 2017, 162(2):457-67.

8. Davidson I, Raibshtein I, Al Tori A, Elrom K. The Consequence of a Single Nucleotide Substitution on the Molecular Diagnosis of the Chicken Anemia Virus. Isr. J Vet Med 2015, 70(2):30-32.

9. Zheng XW, Liu GP, Opriessnig T, Wang ZN, Yang ZQ, Jiang YH. Development and validation of a multiplex conventional PCR assay for simultaneous detection and grouping of porcine bocaviruses. J Virol Methods 2016, 236:164-69.

10. Shackelton LA, Parrish CR, Truyen U, Holmes EC. High rate of viral evolution associated with the emergence of carnivore parvovirus. Proc Natl Acad Sci USA 2005, 102(2):379-84.

11. Jensen TH, Christensen LS, Chriel M, Uttenthal A, Hammer AS: Implementation and validation of a sensitive PCR detection method in the eradication campaign against Aleutian mink disease virus. J Virol Methods 2011, 171:81-85.

12. Costello F, Steenfos N, Jensen KT, Christensen J, Gottschalck E, Holm A, Aasted B: Epitope mapping of Aleutian Mink Disease Parvovirus virion protein VP1 and 2. Scand J Immunol 1999, 49:347-354.

13. Ryt-Hansen P, Hjulsager CK, Hagberg EE, Chriel M, Struve T, Pedersen AG, Larsen LE: Outbreak tracking of Aleutian mink disease virus (AMDV) using partial NS1 gene sequencing. Virol J. 2017, 14(1), https://doi.org/10.1186/s12985-017-0786-5 
14. Kowalczyk M, Horecka B, Jakubczak A. Aleutian Mink Disease Virus in the breeding environment in Poland and its place in the global epidemiology of AMDV. Virus Res 2019, doi: 10.1016/j.virusres.2019.197665.

15. Jakubczak A, Kowalczyk M, Kostro K, Horecka B, Jezewska-Witkowska G: High molecular polymorphism of the hypervariable region in the VP2 gene of Aleutian mink disease virus. Acta Virol 2016, 60:354-360.

16. Li Y, Huang J, Jia Y, Du Y, Jiang P, Zhang R: Genetic characterization of Aleutian mink disease viruses isolated in China. Virus Genes 2012, 45:24-30.

17. Weinberger KM, Bauer T, Bohm S, Jilg WG: High genetic variability of the group-specific a-determinant of hepatitis $\mathrm{B}$ virus surface antigen $(\mathrm{HBsAg})$ and the corresponding fragment of the viral polymerase in chronic virus carriers lacking detectable HBsAg in serum. J Gen Virol 2000, 81:1165-1174.

18. Eibach D, Krumkamp R, Hahn A, Sarpong N, Adu-Sarkodie Y, Leva A, Kasmaier J, Panning M, May J, Tannich E: Application of a multiplex PCR assay for the detection of gastrointestinal pathogens in a rural African setting. BMC Infect Dis 2016, 16

19. Malhotra B, Swamy MA, Reddy PVJ, Kumar N, Tiwari JK: Evaluation of custom multiplex real - time RT - PCR in comparison to fast - track diagnostics respiratory 21 pathogens kit for detection of multiple respiratory viruses. Virol J 2016, 13:91-91.

20. Payungporn S, Chutinimitkul S, Chaisingh A, Damrongwantanapokin S, Buranathai C, Amonsin A, Theamboonlers A, Poovorawan Y: Single step multiplex real-time RT-PCR for H5N1 influenza A virus detection. J Virol Methods 2006, 131:143-147.

21. Raj A, Singh N, Gupta KB, Chaudhar D, Yadav A, Chaudhary A, Agarwal K, Varma-Basil M, Prasad R, Khuller GK, Mehta PK: Comparative Evaluation of Several Gene Targets for Designing a Multiplex-PCR for an Early Diagnosis of Extrapulmonary Tuberculosis. Yonsei Med J 2016, 57:88-96.

22. Sinha P, Prakash P, Patne SCU, Anupurba S, Gupta S, Srivastava GN: Performance of nested multiplex PCR assay targeting MTP40 and IS6110 gene sequences for the diagnosis of tubercular lymphadenitis. J Microbiol 2017, 55:63-67.

23. Payungporn S, Phakdeewirot P, Chutinimitkul S, Theamboonlers A, Keawcharoen J, Oraveerakul K, Amonsin A, Poovorawan Y: Single-step multiplex reverse transcriptionpolymerase chain reaction (RT-PCR) for influenza A virus subtype H5N1 detection. Viral Immunol 2004, 17:588-593.

24. Syring C, Boss R, Reist M, Bodmer M, Hummerjohann J, Gehrig P, Graber HU: Bovine mastitis: The diagnostic properties of a PCR-based assay to monitor the Staphylococcus aureus genotype B status of a herd, using bulk tank milk. J Dairy Sci 2012, 95:3674-3682.

25. Kennedy JA: Diagnostic efficacy of a reverse transcriptase-polymerase chain reaction assay to screen cattle for persistent bovine viral diarrhea virus infection. J Am Vet Med Assoc 2006, 229:1472-1474.

26. Depner K, Bunzenthal C, Heun-Munch B, Strebelow G, Hoffmann B, Beer M: Diagnostic evaluation of a real-time RT-PCR assay for routine diagnosis of classical swine fever in wild boar. J Vet Med B Infect Dis Vet Public Health 2006, 53:317-320.

27. Kilic A, Kalender H, Koc O, Kilinc U, Irehan B, Berri M: Molecular investigation of Coxiella burnetii infections in aborted sheep in eastern Turkey. Iran J Vet Res 2016, 17:41-44.

28. Jensen TH, Christensen LS, Chriel M, Harslund J, Salomonsen CM, Hammer AS: High Prevalence of Aleutian Mink Disease Virus in Free-ranging Mink on a Remote Danish Island. J Wildl Dis 2012, 48:497-502. 
29. Canuti M, Whitney HG, Lang AS. Amdoparvoviruses in small mammals: expanding our understanding of parvovirus diversity, distribution, and pathology. Front Microbiol 2015, doi: 10.3389/fmicb.2015.01119

30. Wang J, Cheng Y, Zhang M, Zhao H, Lin P, Yi L, Tong M, Cheng S: Development of a nanoparticle-assisted PCR (nanoPCR) assay for detection of mink enteritis virus (MEV) and genetic characterization of the NS1 gene in four Chinese MEV strains. BMC Vet Res 2015, 11, doi:10.1186/s12917-014-0312-6

31. Prieto A, Fernandez-Antonio R, Diaz-Cao JM, Lopez G, Diaz P, Alonso JM, Morrondo P, Fernandez G: Distribution of Aleutian mink disease virus contamination in the environment of infected mink farms. Vet Microbiol 2017, 204:59-63.

32. Prieto A, Manuel Diaz-Cao J, Fernandez-Antonio R, Panadero R, Diaz P, Lopez C, Morrondo P, Diez-Banos P, Fernandez G: Application of real-time PCR to detect Aleutian Mink Disease Virus on environmental farm sources. Vet Microbiol 2014, 173:355-359.

\section{DUPLEKS PCR TEHNIKA ZA DOKAZIVANJE VIRUSA ALEUTSKE BOLESTI IZ BIOLOŠKIH UZORAKA I OKRUŽENJA NERČEVA}

\section{KOWALCZYK Marek, JAKUBCZAK Andrzej, GRYZIŃSKA Magdalena}

Aleutska bolest je jedno od najznačajnijih oboljenja nerčeva u intenzivnom, farmskom uzgoju. Oboljenje dovodi do značajnih ekonomskih gubitaka u državama u kojima se nerčevi uzgajaju. Cilj studije je bio da se optimizuje dijagnostička procedura zasnovana na dupleks PCR tehnici u cilju detekcije virusa Aleutske bolesti u biološkim uzorcima nerčeva i u uzorcima iz spoljašnje sredine.

Četrdeset uzoraka krvi i 40 uzoraka slezine životinja koje su bile sumnjive na oboljenje, kao i uzorci briseva iz kaveza u kojima su bile životinje sumnjive na oboljenje $(n=20)$ analizirano je na prisustvo virusa. Iz uzoraka je izolovana DNK, a posle toga je obavljena optimizacija dupleks PCR reakcije sa ciljem dokazivanja sekvenci genoma koji kodiraju NS1 i VP2 proteine. Upotrebljena je qPCR metoda za detekciju osetljivosti reakcije. Specifičnost analize je potvrđena sekvencioniranjem.

Optimizovana dupleks PCR reakcija je omogućila detekciju genetskog materijala virusa uzročnika Aleutske bolesti nerčeva u biološkim uzorcima i u uzorcima iz spoljašnje sredine. Ispitivanjem osetljivosti same metode prikazano je da je dobijena jasna amplifikacija oba para prajmera sa 102 kopija virusne DNK. Sekvencioniranjem, obavljena je potvrda specifičnosti reakcije pri čemu u slučaju oba para prajmera ustanovljeno 90\% slaganja između izolata i varijanti virusa iz banke podataka.

Primena dupleks PCR tehnike radi dokazivanja dva regiona u genomu virusa uzročnika Aleutske bolesti nerčeva može da poveća osetljivost i specifičnost metode i da značajno poboljša mogućnosti daljih analiza zasnovanih na sekvencioniranju. 